\title{
Correction to: The pleiotropic effects of prebiotic galacto-oligosaccharides on the aging gut
}

Jason W. Arnold ${ }^{1,2}$, Jeffery Roach ${ }^{2,3}$, Salvador Fabela ${ }^{1,2,4}$, Emily Moorfield ${ }^{5}$, Shengli Ding ${ }^{5}$, Eric Blue ${ }^{5}$, Suzanne Dagher ${ }^{6}$, Scott Magness ${ }^{7}$, Rita Tamayo ${ }^{8}$, Jose M. Bruno-Barcena ${ }^{6}$ and M. Andrea Azcarate-Peril ${ }^{1,2^{*}}$

\section{Correction to: Microbiome 9, 31 (2021) \\ https://doi.org/10.1186/s40168-020-00980-0}

Following publication of the original article [1], an error was identified in Fig. 4. The correct figure is given below.

The original article [1] has been updated.

\section{Author details}

'Department of Medicine, Division of Gastroenterology and Hepatology, School of Medicine, University of North Carolina, Chapel Hill, NC, USA. ${ }^{2}$ UNC Microbiome Core, Center for Gastrointestinal Biology and Disease (CGIBD), School of Medicine, University of North Carolina, Chapel Hill, NC, USA. ${ }^{3}$ UNC Information Technology Services and Research Computing, University of North Carolina, Chapel Hill, NC, USA. ${ }^{4}$ Current affiliation: Programa de Inmunología Molecular Microbiana. Departamento de Microbiología y Parasitología, Facultad de Medicina, Universidad Nacional Autónoma de Mexico, Mexico City, Mexico. ${ }^{5}$ Department of Cell Biology and Physiology, University of North Carolina, Chapel Hill, NC, USA. ${ }^{6}$ Department of Plant and Microbial Biology, North Carolina State University, Raleigh, NC, USA. ${ }^{7} J o i n t$ Department of Biomedical Engineering, University of North Carolina, Chapel Hill and North Carolina State University, Raleigh, NC, USA. ${ }^{8}$ Department of Microbiology and Immunology, University of North Carolina, Chapel Hill, NC, USA.

Published online: 26 February 2021

\section{Reference}

1. Arnold JW, Roach J, Fabela S, et al. The pleiotropic effects of prebiotic galacto-oligosaccharides on the aging gut. Microbiome. 2021;9:31 https:// doi.org/10.1186/s40168-020-00980-0.

\footnotetext{
The original article can be found online at https://doi.org/10.1186/s40168020-00980-0.

* Correspondence: azcarate@med.unc.edu

'Department of Medicine, Division of Gastroenterology and Hepatology, School of Medicine, University of North Carolina, Chapel Hill, NC, USA ${ }^{2}$ UNC Microbiome Core, Center for Gastrointestinal Biology and Disease (CGIBD), School of Medicine, University of North Carolina, Chapel Hill, NC, USA

Full list of author information is available at the end of the article
}

(c) The Author(s). 2021 Open Access This article is licensed under a Creative Commons Attribution 4.0 International License, which permits use, sharing, adaptation, distribution and reproduction in any medium or format, as long as you give appropriate credit to the original author(s) and the source, provide a link to the Creative Commons licence, and indicate if changes were made. The images or other third party material in this article are included in the article's Creative Commons licence, unless indicated otherwise in a credit line to the material. If material is not included in the article's Creative Commons licence and your intended use is not permitted by statutory regulation or exceeds the permitted use, you will need to obtain permission directly from the copyright holder. To view a copy of this licence, visit http://creativecommons.org/licenses/by/4.0/ The Creative Commons Public Domain Dedication waiver (http://creativecommons.org/publicdomain/zero/1.0/) applies to the data made available in this article, unless otherwise stated in a credit line to the data. 


\section{a}
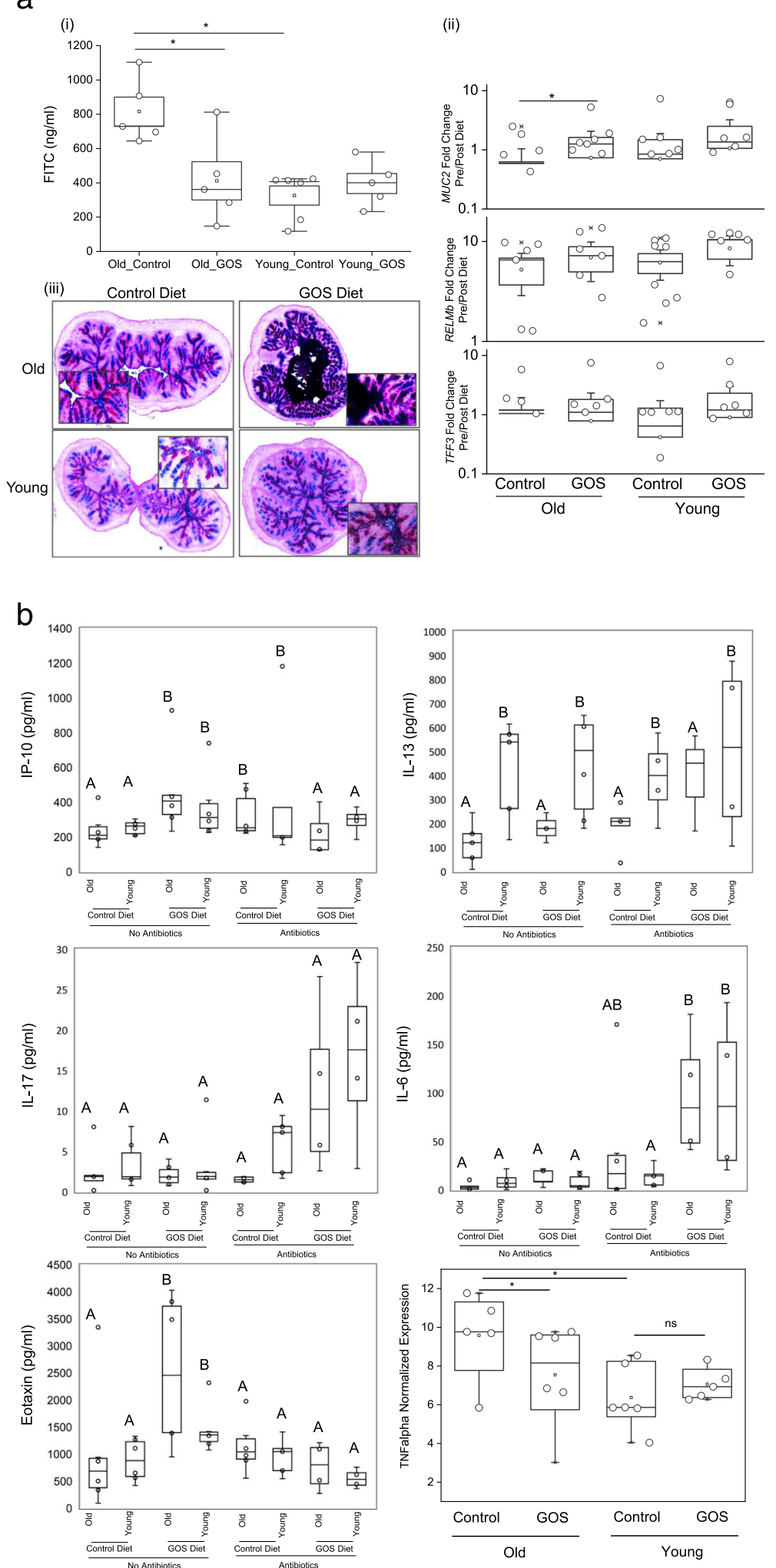

Fig. 4 (See legend on next page.) 
(See figure on previous page.)

Fig. 4 a (i) Old mice had higher intestinal permeability measured by FITC-dextran assays than young animals. (ii) Old mice fed GOS had significantly increased MUC2 expression ( ${ }^{*} p<0.05$ ). The expression of TFF3 and RELMb tended to increase in the GOS groups, but differences were not statistically significant. (iii) Paraformaldehyde vapor fixation and subsequent PAS staining showed increased mucus thickness in old mice fed the prebiotics diet. $\mathbf{b}$ Inflammatory biomarkers were modulated by antibiotics and GOS. A $2 \times 2 \times 2$ ANOVA test showed (i) increased serum IP-10 in GOS-fed animals without antibiotic treatment and in antibiotic-treated animals fed control diet. (ii) Serum IL-13 levels were higher in young animals than in old animals in all groups. (iii) IL-17 levels were higher in antibiotic-treated animals than in animals without antibiotics. (iv) IL-6 was increased in antibiotic-treated old animals (GOS and control) compared to old animals without antibiotic treatments and elevated in young animals treated with both GOS and antibiotics. (v) Eotaxin levels were higher in GOS-fed animals without antibiotic treatment, but lower in GOS-fed animals that received antibiotics, regardless of age. (vi) Expression of TNFa quantified by RT-qPCR was higher in old animals compared to young and reduced by GOS treatment in old animals 